\title{
Export Performance in the Reform Era: Has India Regained the Lost Ground?
}

\author{
Prema-chandra Athukorala \\ Division of Economics and Australia South Asia Research Centre \\ Research School of Pacific and Asian Studies \\ Australian National University \\ Prema-chandra.athukorala@anu.edu.au
}

updated February 2008 


\section{Export Performance in the Reform Era: Has India Regained the Lost Ground?}

During the first four decades of the post-independence era India continued to remain an underperformer in world export markets, relative to both her own potential and the performance of many other developing countries. The consensus of the sizeable literature on this subject is that domestic economic polices, rather than external demand conditions, were largely to be blamed for the poor export performance. ${ }^{1}$ The overriding aim of the Indian development policy from the inception was across-theboard import substitution in the context of a foreign trade regime which relied extensively on quantitative restrictions (QRs). Until about the mid-1970s the overall policy trend was towards tightening controls on both foreign trade and domestic industry. The pull of resources into import-substitution industries by the high level of protection, plus overvaluation of the real exchange rate resulting from upwards shift in demand for imports and a rate of domestic inflation above that of trading partners, discouraged production for export. Also, the inflexibilities created by the pervasive controls on domestic manufacturing handicapped the ability of firms to penetrate export markets.

As a reaction to the foreign exchange constraint on economic growth, export promotion was recognized as a policy goal in the late 1960s, but export performance continued to be constrained fundamentally by "the inward-looking framework in which exports are treated essentially as an after thought" (Wolf 1982: 12). Also, the export incentives granted were concentrated on a few manufacturing sectors and most

\footnotetext{
${ }^{1}$ The first systematic analysis of India's export performance and potential, which cogently argued that India's export stagnation was largely 'home made', was by Manmohan Singh (Singh 1964). Since then, there have been a number of other important analyses in the same vein, reinforcing the view that India's exports could be significantly increased through policy reforms and poor export performance was a significant factor in India's lack-luster economic performance in general (eg. Wolf 1982, Bhagwati and Desai 1970, Bahagwati and Srinivasan 1975, Krueger 1975, Joshi and Little 1994 and 1996). The title of this paper has been adapted from Singh (1966): 'The ground lost as a result of neglecting exports in the past could [not] be easily reversed in the future' (p. v).
} 
agricultural exports were not eligible for these incentives but subjected to export duties at varying rates. Some liberalization took place during 1975-1991, especially during the last five to seven years, including progressive loosening of import controls and increase in subsidies to exporters of manufactured goods. However, in the absence of significant policy initiatives to redress exchange rate overvaluation and domestic industrial licensing, the policy bias against export performance remained virtually unchanged (Joshi and Little 1994). Thus, sluggish export growth continued to act as a drag on economic growth, both by impairing capacity to import developmental imports and by limiting the expansion of domestic industry to the confine of the domestic market. The Growth was not merely low but also distorted; failure to penetrate word markets in labour-intensive products infused an undue capital-intensity bias to domestic manufacturing, with adverse implications for employment generation, income distribution and poverty alleviation (Bhagwati 1993).

The liberalisation-cum-structural adjustment reforms initiated in 1991 marked a clear departure from the dirigiste past (Joshi and Little 1996, Krueger and Chinoy 2002, Srinivasan and Tendulkar 2003, World Bank 2000). How far has this policy turnaround been successful in recovering India's lost ground in export trade? How does India's performance compare with that of other countries? In particular, how well India has succeeded in diversifying into dynamic export products? Are the emerging export patterns in line with India's comparative advantage ('pro-poor')?, This Chapter aims to shed light on these and related issues by examining export performance of India in the reform era against the backdrop of pre-reform experience and compared with China and of other major developing countries.

The paper begins with a survey of export trends by dividing the postindependence period into four sub-periods, each of which marked by distinctive shifts 
in policy regimes: the immediate post-independence period characterised by liberal trade and investment policies, the era of economic dirigisme from the early 1960s, the period of reforms by stealth from the late 1970s and the era of significant liberalization reforms since 1991. This is followed by an analysis of comparative export experience by major commodity categories, changing revealed comparative advantage in world trade and factor-intensity characteristics of the emerging export patterns. The final section draws policy inferences, with a focus on the contemporary debate on the feasibility and the desirability (from the view point of laying a solid foundation for achieving sustained, equitable growth) of bypassing the stage of labour- intensive export expansion.

\section{Export Trends}

India's merchandise exports grew (in current US\$ terms) at an annual arte of about $5 \%$ in the first there decades of post-independent period in a context whether world export was expanding at an annual rate of over $10 \%$. Consequently India's share of world none-oil exports fell persistently from 2.3 in the 1950 s to $0.6 \%$ in the 1970 s (Table 1). ${ }^{2} \quad$ Notwithstanding some selective measures introduced to ameliorate the anti-export bias, India's export growth rates continued to remain below world trends in the 1980s, and India's share world market share fell to an average level of $0.5 \%$.

\section{Table 1 about here}

As can be seen in disaggregated data reported in Panel c in Table 1, the fall in India's share in total exports from developing countries during the period was much sharper (from 3.2 in the 1960s to $1.5 \%$ during the 1980s) compared to the fall in

\footnotetext{
2 In 1948, India's share of world merchandise exports (2.2\%) was five times of that of Japan (0.4) (Srinivasan and Tendulkar 2003, p. 2).
} 
her share of total world exports. Moreover, India's failure to keep up with overall export performance of other developing countries is much more clearly visible in manufacturing trade; India share in total manufacturing exports from developing countries plummeted from $10.2 \%$ in the 1960 s to $2.6 \%$ in the 1980 s (Figure 1). In 1962/3 (the earliest years for which comparable country-level data are available) India was the second largest exporter of manufactured good in the developing world (accounting for 17.8\% of exports) after Hong Kong (19.8\%) (Table 2). The ranking dropped to the $9^{\text {th }}$ position in $1979 / 80$, when India accounted for only $4.3 \%$ of total manufacturing exports from developing countries. By the time of 1991 reforms, India was the tenth largest exporter (2.6\%) after the Philippines (2.9\%) and India's export share amounted to less than one eighth of that of China (25.5\%). The degree of export orientation of the economy, measured by exports to GDP ratio, remained virtually unchanged around 6\% throughout the 1970s and 1980s (Figure 2).

\section{Figure 1 about here}

Figure 2 about here

\section{Table 2 about here}

The Indian economy began to record higher growth in both services and merchandise exports following in the reform era. Merchandise exports grew at an average annual rate of $12.6 \%$ during $1991-05$ compared to $8.1 \%$ in the 1980 s. Total exports (merchandise + service) grew at a faster rate (14.2\%) reflecting faster growth of services. The degree of export orientation of the economy increased from $6.1 \%$ in the 1980 s to $12.2 \%$ during 1991-05. Export growth and the degree of export orientation were much faster in the first five years of the new millennium compared to the previous decade. Rapid services growth largely emanated from the information 
technology sector and business related information services (Acharya 2006, Desai 2000, Saxsenian 2000). Services share in total exports increased from $15.9 \%$ in the 1970 s to $23.3 \%$ in the 1980 s and then to $24.6 \%$ during $1991-05$.

India's share in total world merchandise trade, which had persistently declined over the past for decades reaching a historical low of $0.50 \%$ in the mid 1980 s, recoded a modest, but persistent recovery from the early 1990s, reaching 1\% mark in 2005 (Figure 1a). However, as yet there has not been any noticeable increase in India's share in developing country exports, both total merchandise exports and manufactured exports. These shares have hovered between $2 \%$ to $2.5 \%$ without showing any discernable trend (Figure 1b). Between, 19990/00 and 2005/06, India's ranking in manufactured exports among developing countries improved marginally from $10^{\text {th }}$ to $8^{\text {th }}$, but her market share (2.7\%) amounted to less than one fifteenth of that of China (38.1) (Table 2). Overall, I India's modest market share gains in recent years have been at the expense of exports from developed countries. There is no sign that the reform processed had contributed to improving India's export competitiveness compared to the other developing countries.

\section{Export Patterns}

In this section India's export performance is examined from a comparative regional (Asian) perspective against the backdrop of pre-reform experience and the on-going changes in patterns of international production. The relevant data are summarized in Table 3 and 4.

Table 3 about here

Table 4 about here 
Rapid export growth in developing Asian countries over the past three decades has been underpinned by a pronounced shift in export structure away from primary commodities and toward manufactures (Tables 3). By 2005/06 manufactures accounted for $92 \%$ of total exports from these countries, up from $78.3 \%$ three decades ago. Given the nature of their resource endowments, the four Asian NIEs (Hong Kong, Taiwan, Korea, and Singapore) relied very heavily on manufacturing for export expansion from the very beginning. However, beginning in the 1970s, a notable shift towards manufacturing is observable across all countries, at varying speeds and intensity. The share of manufactured in the export composition of India increased from $57.8 \%$ in $1979 / 80$ to $72 \%$ in $1989 / 90$ and to $78.1 \%$ in $2005 / 06$. This structural shift, though noteworthy, is far less dramatic compared to the experiences of dramatic compared to all second-tier exporting countries ${ }^{3}$ in the region, particularly when we take into account the fact that historically India had a relatively well established manufacturing base to begin with (Wolf 1983).

Developing Asia’s share in total world manufacturing exports increased from $19.5 \%$ in $1979 / 80$ to $36.6 \%$ in $2005 / 6$. India still accounts for a tiny share, around $1 \%$, at the end of the period. China's rise has been the key factor behind the rapid growth of manufacturing exports from developing Asia, but exports from Taiwan, Korea, and the ASEAN countries have also recorded impressive growth.

Within manufacturing, machinery and transport equipment (SITC 7, henceforth referred to as 'machinery' for short) has been the prime source of export dynamism in China and the other East Asian countries over the past two decades. Information and communication technology (ITC) products have the dominant category with machinery exports. In all East Asian countries listed in Table 3,

\footnotetext{
3 This term is used to referrer to the dynamic exporting countries in East Asia other than the four newly-industrialized economies (NIEs) (Korea, Taiwan, Honk Kong and Singapore).
} 
machinery category accounted for nearly half or more of total manufacturing exports by 2005/06, with ICT product accounting for over two-thirds of exports of within machinery group. By contrast, the share of machinery in manufacturing exports from India in 2005/06 amounted to a mere $11 \%$, and ICT products accounting for a mere 4\%. Clearly, India’s much talked about high-tech bias in domestic manufacturing has not yet begun to reflect in her export structure. India's export structure is notable for its heavy reliance on resource-based manufacturing (SITC 6) which accounted for nearly a half of total manufacturing exports in 2005/06.

The fast growth of machinery exports, in particular of ICT products therein, from Asia has been driven by rapid growth of international fragmentation of production in world trade and the increasingly deep integration of East Asian countries into the global production networks that proliferated as a result of these two, more or less simultaneous developments (Athukorala 2006b). The best available indicator of the intensity of fragmentation-based specialization in the region is the share of parts and components ${ }^{4}$ in total recorded trade in machinery and transport equipment. These data are summarised in Table 5. The share of Developing East Asia (DEA) in world component exports increased from $16.5 \%$ to $28.1 \%$. Within DEA, all countries covered in our data tabulations have recorded increases in world market shares, with the ASEAN countries exhibiting faster increases compared to the regional average. In countries such as Malaysia, Thailand and the Philippine components accounts for a large share of total machinery exports. Interestingly, the significant increase in the relative importance of DEA in fragmentation trade has taken place against the backdrop of a notable decline in the shares of both NAFTA and EU. However, India remains a tiny participant in the global production networks

\footnotetext{
${ }^{4}$ Henceforth, for the sake of brevity, we use the term 'components' in place of 'parts and components'.
} 
even though it has great potential to benefit from this new form of international specialization, given the relatively low-cost and trainable labour, and its location in a region that has become the growth centre of component production and assembly in the world. In 2005/6 India accounted for a mere 0.3\% of component exports and $0.2 \%$ of final good exports in world machinery trade.

\section{Table 5 about here}

Asia's share in the other main product categories has also increased over time, though at a slower rate. Of particular interest here is the notable increase in region's share in miscellaneous manufacturing. This mostly consists of standardized labourintensive manufactured goods, in particular clothing and footwear. China has accounted for the lion's share of this increase but, in contrast to ICT exports, the geographic participation has been broader. A number of low-wage countries in Southeast and South Asia, including Indonesia, Vietnam, India, Sri Lanka, Bangladesh, and Cambodia (not listed in the table) have all recorded impressive gains in market share.

In the lead-up to the abolition of the Multifibre Arrangement in December 2004 there was much speculation in policy circles that India and China would be the biggest winners of this historic step to significantly liberalize the world textile and clothing trade. ${ }^{5}$ However, India's market share gain over the past two years of the post-MFA era has been much smaller compared to that of China (Figure 3). In 2006 China accounted for nearly 30\% of world textile and clothing exports (up from up from 23\% in 2004). Comparable figure for India was 4\% (up from 3\% in 2004).

\footnotetext{
${ }^{5}$ See Nordas (2004) and the work cited therein. Based on WTO modeling work, Nordas (2004) predicted that after the MFA abolition India's share in world textile and clothing exports would increase to $11 \%$ and $15 \%$ respectly (implying an increase in the combined share to about $12 \%$ ).
} 
India's share in world textile and clothing and exports (3.2\% in 2005/6) - a key indicator of early stage, labour-intensive exports - was only little more than that of Bangladesh (2.6\%).

\section{Figure 3 about here}

\section{Revealed comparative advantage}

What are the products in which India has performed better in world markets compared to its overall export performance? Has the list of products which meet this criterion expanded or shrunk during the reform era? A useful analytical tool that helps answer these issues is the index of revealed comparative advantage (RCAI), which measures a country's relative export performance in individual product categories compared to its overall export performance in world trade (Balassa 1965).

The RCAI of a given country (country $I$ ) in the export of product $j$ is defined as:

$R C A I_{J}^{I}=\frac{\left[X_{J}^{I} / X_{J}^{W}\right]}{\left[X_{T}^{I} / X_{T}^{W}\right]}$

where, $X_{j}^{I}$ is country I's exports of commodity $J, X_{J}^{W}$ is world export of commodity $j, X_{T}^{I}$ is total exports of all goods from country $\mathrm{I}$, and $X_{T}^{W}$ is world exports of all goods. If the value of RCAI exceeds unity for commodity $J$, the country is said to have 'revealed' comparative advantage in the production of that commodity. In contrast, if RCAI is below one, the country is at a comparative disadvantage in the production of the commodity.

We estimated RCAIs for India exports at three time points (1980/81, 1990/91 and 2004/5) using data at the 3-digit level of the Standard International Trade 
Classification (SITC). The analysis covers total merchandise exports excluding oil and gas (STIC 3) and special export items listed under SITC 9. In Table 6, RCAIs are reported together with data on percentage composition of exports and world market share of each commodity to facilitate the analysis. The table covers all threedigit products with a 'revealed comparative advantage' (that is $1<\mathrm{RCAI}$, referred to as 'RCA products' in the following discussion) in any of the three time points.

The first impression from a comparison of RCA estimates is that the revealed comparative advantage in world trade of both countries is broad-based, unlike that of many developing countries whose strength in international exchange lies in one or a few products. This pattern is only to be expected for an economy like India with a diver resource base. However, there is no clear evidence as yet of a clear pattern of export specialization emerging; revealed comparative advantage is dispersed over a large number of products. In 1990/91 there we there were 47 RCA products which accounted for $81 \%$ of total exports. The number of products increased to 61 in 2004/5, but their combined share in total exports declined to $72 \%$.

\section{Table 6 about here}

Primary products (food beverages and tobacco, agricultural raw material and mineral) have continued to occupy a relative more important position among RCA products compared to manufactured goods (products belonging to SITC categories 5 though 8). Within manufacturing, India's comparative advantage has continued to remain concentrated in domestic-resource based products (SITC 6). Traditional labour intensive manufactures (products belonging to SITC 8) occupies a relatively low position in RCA ranking, notwithstanding India's obvious comparative advantage 
in these product lines. None of the products belonging to machinery and transport equipment category (SITC 7), which has been the main vehicle for rapid growth in world trade, show RCA status in the India export structure in 2004/5.

\section{Factor Intensity Decomposition of Merchandise Export}

As noted at the outset, a much written-about aspect of pre-reform export performance in India is the inconsistency of export patterns in line with the country's intrinsic comparative advantage in labour intensive products. Has this pattern changed during the reform era? A definitive answer to this question can only come a systematic analysis of the link between emerging export patterns and changing factor proportions in domestic manufacturing through micro-level industrial performance data. This is beyond the scope of this study. Here we simply attempt to gain some preliminary insights by using the standard method of factor proportion decomposition of reported export pioneered by Lary (1968) and developed subsequently by Leamer (1983) and others.

This method is based on the assumption that factor intensity rankings of industries/products are internationally consistent, that is, an industry that was relatively labour-intensive in a poor country was similarly so in a rich country. The validity of this assumption has become highly questionable because of the on-going process of international production fragmentation, which has opened up opportunities for countries to specialize in various segments of the production process within vertically integrated global industries in line with their comparative advantage. For instance a country might be exporting computers (which are classified as skillintensive under the standard classification system) but the country is actually in involved in final assembly (a labour-intensive task) using capital- and skill-intensive 
parts and components imported from countries which at an advanced stage of the industrialization process. However, as we have already observed, fortunately [for the purpose of this analysis] Indian has not yet become a significant participant in fragmentation-based international division of labour. So the standard decomposition procedure still remains useful 'shortcut' to gain some sight into changing factor intensity patterns in Indian exports.

The result of our factor intensity decomposition exercise based on export data for the period 1976 to 2004 is depicted in Figure 4. The share of primary (land intensive) products in the export composition has declined persistently from about the early 1980s, reflecting the growing importance of manufacturing produces (the sum of the other four factor intensity categories). Within manufacturing, shares of capitalintensive (medium tech) and skill-intensive (high-tech) products have increased persistently from the mid 1980s, though from low bases, with the rate of increase accelerating over the past decade or so. The share of resource based manufacturing, which recorded a mild increased from about the late 1990s to mid 1990s, has increased persistently since then. Interestingly, the share of labour-intensive products has recorded a mild, but persistent, decline throughout the reform period (since 1991) compared to the previous decade. Labour intensive products accounted for $32 \%$ of total exports in 2005, compared to over $40 \%$ in the early 1990 s. The most notable shift in the export mix during the reform era has been from land-intensive products to resource-based manufacturing. The high-tech bias in domestic manufacturing noted in a number of recent studies (Huang and Khanna 2003, Kochhar et al. 2006, Das 2006) has not yet become prominent on the export side.

\section{Figure 4 about here}




\section{Policy Issues}

We have seen evidence of India's improved performance both in services and merchandise exports over the past one-and-a-half decades. However, it is not yet clear, particularly in the case of merchandise trade (which still account for over three-froths of total export earnings), whether the improved performance in solidly based on sustained expansion of exports with long-run growth prospects and which are in line with India's comparative advantage. Export performance during the reform era has been dominated by resource-intensive manufacturing. So far there are no clear signs of India entering into global and regional production networks in machinery and transport equipment which have been the prime mover of export dynamism in successful export-oriented economies in East Asia. Overall, India's share in exports from developing countries, which plummeted throughout the period from the early 1960s to until about the late 1980s, has remained stagnant around $2 \%$ since then. Most of the mild gain in India share in total world merchandise trade has come solely from competition with exports from developed countries.

Notwithstanding India’s comparative advantage in labour intensive production, there has been a structural shift in exports away from labour intensive products and toward resource-, capital- and skill-intensive products. In the area of labour intensive exports, India is still heavily reliant on textile and clothing. Even in this product category, India’s performance has been far less impressive compared not only to China but also a number of other latecomer exporting countries in the region.

Some recent studies on India's export performance have come up with the view that the performance and patterns of Indian exports during the reform era (as summarised above), in particular India's failure so far to rely effectively on the East Asian model of labour-intensive exports as the main pillar of economic expansion, a 
peculiar 'Indian model' rooted in the industrial history of the country (eg. Rodrik and Subramanian 2005, Kochhar et al. 2006). According to this school of though, India's future growth prospects would be primarily determined by the expansion of domesticmarket oriented high- and medium-tech industries, with services sectors (in particular soft-wear and IT set vices, call-centers etc.) playing the key role in export expansion. India's achievement in services exports over the past decade has of course been impressive and there is amply room for further growth in this area. However, it is not clear how India can achieve sustained equitable growth without restricting domestic manufacturing to redress its long-standing capital-intensity bias though rapid expansion of labour intensive products. Despite over ten-fold increase in output over the past decade, total (direct and indirect) labour absorption in India information technology industry is currently amount to mere $1 \%$ of total employment in the country (Bardhan 2006). Moreover, employment in information-technology services naturally has a skill-intensity bias. The only effective avenue for providing gainful employment for the vast pool of unskilled and semi-skilled labour remains the expansion of labour intensive manufacturing (Panagariya 2006). Making the growth process equitable through employment generation is vital for the sustainability of market-oriented policy reforms. It is ironic if the new found enthusiasm for servicesoriented growth were to distract the government from undertaking necessary measures to promote export-oriented growth in traditional labour intensive industries.

The school of though which advocate a services-oriented growth strategy for India is based on the implicit assumption that India's lack-luster achievement so far in labour-intensive real-sector growth is an 'inescapable phenomenon', an outcome of various factors beyond the control of the reform process. However, there are strong 
reasons to argue that explanation lies in economic policies, in the incomplete reform agenda.

Relative to the first four decades following independence, India's policy reforms since 1991 have certainly achieved a great deal in unshackling the economy and integrated it into the world economy. However, there are still many unresolved problems relating to the overall investment climate in general and the anti-export bias in the policy regime in particular (Feldstein 2006, Krueger and Chinoy 2002, Srinivasan 1998 and 2004, Panagariya 2006).

Despite notable tariff reforms since the early 1990s, tariff protection in India is still substantially higher than in most other developing countries in the region. While a systematic analysis of the anti-export bias in the incentive regime is yet to be done, the available data on minimal and effective rates of protection (reported in Tables 7 and 8) suggest that the incentive structure still discriminates against export-oriented production and in favour of domestic-market oriented production. The effective rate of protection for domestic production in India is more than twice of the average level in Indonesia, Malaysia, Philippines and Thailand. Moreover, in India, consumer goods industries, which are the basis for labour-intensive manufacturing export expansion, are generally more insulated from international competition compared to capital and intermediate goods industries. In addition to relatively tariffs, India also rank poorly among Asian countries in terms of various other indicators of ease of doing business across border (Table 9)

\section{Table 7 about here}

\section{Table 8 about here}

Table 9 about here 
There is also a significant unfinished agenda of 'behind-the-border' reform. Regulation impacting on private sector activities has become less onerous since the start of the reforms, but there are various are sector-specific regulations in abundance. While, the 'the License Raj' (the infamous industrial licensing policy) has been largely eliminated at the centre, it still survives at the state level, along with a pervasive ‘Inspector Raj’. Private investors require a large number of permissions (eg. Electricity and water supply connections, water supply clearance etc.) from state governments to start business and they also have to interact with the state bureaucracy in the course of day-to-day business. Notwithstanding some relaxation in recent years, the ‘small scale industries' reservation policy, under which designated industries are reserved only for tiny companies that are unable to compete with the large firms, still remains a major constrain on the expansion of labour intensive manufacturing where India’s comparative advantage in international production lies (Das 2006). ${ }^{6}$ Stringent labour laws and restrictive labour market practices are among other prominent issues. These issues are reflected in India's poor ranking among the countries in the region, in particular the dynamic export-oriented economies in East Asia, in terms of various indicators of ease of doing business (Table 10).

\section{Table 10 about here}

Despite recent reforms, India's foreign investment regime still reflects the tension between the traditional aversion to foreign investment and the current recognition of its importance to economic development. In clothing and other light consumer-good producing industries, which are important in export expansion and job

\footnotetext{
${ }^{6}$ Clothing was removed from the reservation list in 2000. This presumable set the stage for the expansion of clothing exports from India following the termination of the Multifibre Arrangement in 2005.
} 
creation at the current stage of economic development of the country, FDI is limited to $24 \%$ of total equity. Restrictions on foreign ownership of land limit the entry of foreign builders and developers in to the construction sector. Projects with $51 \%$ or more foreign ownership still require a long procedure of government approval (Athukorala 2007, Chapter 2).

Given these remaining restrictive elements in the investment regime and the relatively poor overall business climate in the countries India has continued to remain under performers in attracting FDI. Much of FDI in the country (other than that in the software and IT sectors) has been in domestic-market oriented (tariff-jumping) production. Failure to attract MNEs engaged in international production networks has been a key factor behind India's inability to benefit from the thriving productionfragmentation related international specialization in high-tech industries.

The remarkable success in the global software and information technology industries highlights India's potential to grow through export-oriented FDI under more liberal trade and investment regimes. The software industry is unique in India in that the restrictions on MNE entry have been virtually abolished. This was also accompanied by the removal of quantitative restrictions on imports of computers and peripherals, and drastic cuts in import tariffs on these products. This combination of FDI and trade liberalization laid the foundations that made the domestic software industry internationally competitive. Now virtually every major global company in the software industry has a base in India and the entry of MNEs has opened up opportunities for Indian companies to thrive through functional specialization, and to develop niche products and services for large clients abroad. As one commentator puts it, 'the success of foreign investment in the software industry is a measure of the failure of India’s restrictions on foreign investment elsewhere’ (Desai 2002, p 205). 


\section{REFERENCES}

Acharya, Shankar (2006), Essays on Macroeconomic Policy and Growth in India, Delhi: Oxford University Press.

Athukorala, Prema-chandra (2005), 'Trade Policy in Malaysia: Liberalization Process, Structure of Protection, and Reform Agenda', ASEAN Economic Bulletin, 22(1), 1934.

Athukorala, Prema-chandra (2006a) 'Trade Policy Reforms and the Structure of Protection in Vietnam', World Economy, 29(2), 161-87.

Athukorala, Prema-chandra (2006b), 'Production Fragmentation and Trade Patterns in East Asia', Asian Economic Papers, 4(3), 1-27

Athukorala, Prema-chandra (2007), Multinational Enterprises in Asian Development, Cheltenham, UK: Edward Elgar.

Balassa, Bela (1965), 'Trade Liberalization and 'Revealed' Comparative Advantage', Manchester School, 33(2), 99-123.

Bhagwati, Jag dish. (1993), India in Transition: Freeing the Economy, Oxford: Clarendon Press.

Bhagwati, Jagdish and Padma Desai (1970), India: Planning for Industrialization, London: Oxford University Press.

Bhagwati, Jagdish and T.N. Srinivasan (1975), Foreign Trade Regimes and Economic Development: India, New York: Colombia University Press.

Das, Gurcharan (2006), 'The India Model', Foreign Affairs, 85(4), 2-9.

Desai, Ashok V (2002), 'Comments' (on Saxsenian 2002), in Anne O Krueger (ed.), Economic Reforms and the Indian Economy, Delhi and Oxford: Oxford University Press, 20-3-210.

Fane, G. and T. Condon (1996), 'Trade Reforms in Indonesia:, 1987-1995', Bulletin of Indonesian Economic Studies, 27(1), 105-125.

Feldstein, Martin (2006), ‘There’s more to Growth than China’, Wall Street Journal, February 16, p. 6.

Government of India. (2003), Economic Survey 2002/3, New Delhi: Ministry of Finance.

Hunag, Yashen and Tarin Khanna (2003), 'Can India Overtake China?', Foreign Policy, Jul/Aug, 137, 74-81.

Jongwanich, Juthahip and Archanun Kohpaiboon (2007), 'Determinants of Protection in Thai Manufacturing', Economic Papers, 26(3, 276-294.

Joshi, Vijay and I.M.D. Little. (1994), India: Macroeconomics and Political Economy 19641991, Washington DC: World Bank.

Joshi, Vijay and I.M.D. Little. (1996), India's Economic Reforms 1991-2001, Oxford: Clarendon Press.

Kochhar, Kalpana, Utsav Kumar, Raghuram Rajan, Arvind Subramanian and Ioannis Tokatlidis (2006), India's pattern of Development: What Happened, What Follws?', Working Paper WP/06/22, Washington DC: IMF.

Krueger, Anne O. (1975), The benefits and Costs of Import Substitution in India: A Microeconomic Study, Minneapolis, MN: University of Minnesota Press.

Krueger, Anne O. and Sajjid Chinoy (2002), 'The Indian Economy in Global Context', in Anne O Krueger (ed.), Economic Policy Reforms and the Indian Economy, New Delhi: Oxford University Press, 9-46.

Lary, Hal B. (1968), Imports of Manufactures from Less Developed Countries, New York: Columbia University Press. 
Leamer, Edward E (1984), Sources of International Comparative Advantage: Theory and Evidence, Cambridge, MA: MIT Press.

Nayyar, Deepak (1976), India's Exports and Export Policies in the 1960s, Cambridge: Cambridge University Press.

Nicita, A and M Olarreaga (2006). Trade, Production and Protection 1976-2004. Washington DC: World Bank (www.worldbank.org)

Nordas, Hildegunn Kyvk (2004), The Global textile and Clothing Industry Post the Agreement on Textiles and Clothing', Discussion Paper No 5, Geneva: WTO.

Panagariya, Arvind (2006), 'Transforming India', paper presented at the conference, 'India: An Emerging Giant', October 13-15, 2006 at Colombia University.

Rodrik, Dani and Arvind Subramanian (2005), 'From "Hindu Growth” to Productivity Surge: The Mystery of the Indian Growth Transition', IMF Staff Papers, 52(2),193- 228.

Saxsenian, Annalee (2002), ' Bangalore: The Silicon Valley of Asia?’, in Anne O Krueger (ed.), Economic Reforms and the Indian Economy, Delhi and Oxford: Oxford University Press, 169-193.

Sen, Kunal (2008), 'Trade, FDI and Industrial Transformation in India', paper presented at the research workshop, 'Emerging Trends and Patterns of Trade and Investment in Asia', Ninth Global Network Conference, Brisbane, Australia, 1-2 February.

Singh, Manmohan (1964), India's Export Trends, Oxford: Clarendon Press.

Srinivasan, T.N. (1998), 'India's Export Performance: A Comparative Analysis, in Isher J. Ahluwalia and I.M.D. Little (eds.), India's Economic Reforms and Development: Essays for Manmohan Singh, pp.197-228. Delhi: Oxford University Press, Delhi.

Srinivasan, T.N. (2004), 'Integrating India with the World Economy', in Anne O Krueger and Sajjid Z. Chinoy (eds.) Reforming India's External Finance and Fiscal Policy, New Delhi: Oxford University Press, 17-56..

Srinivasan, T.N. and Suresh D. Tendulkar (2003), Reintegrating India with the World Economy. Washington DC: Brookings Institution Press.

Wold, Martin (1982), India's Exports, New York: Oxford University Press.

World Bank. (2000), India: Reducing Poverty, Accelerating Development. New Delhi: Oxford University Press.

WTO (World Trade Organization) (1999), Trade Policy Review: Philippines 1999, Geneva: WTO. 
Table 1: Key Indicators of India's Export Performance, 1950-2005

\begin{tabular}{|c|c|c|c|c|c|c|c|}
\hline & $1950-59$ & 1960-69 & $1970-79$ & $1980-89$ & $1990-99$ & $2000-05$ & 1991-05 \\
\hline \multicolumn{8}{|l|}{ (a) Annual average export growth ${ }^{\#}$} \\
\hline Total (merchandise + services) exports & --- & 7.1 & 7.3 & 7.9 & 9.9 & 21.2 & 14.2 \\
\hline Merchandise exports & 5.1 & 4.6 & 6.8 & 8.1 & 8.9 & 18.9 & 12.6 \\
\hline \multicolumn{8}{|l|}{ (b) Exports as a percentage of GDP } \\
\hline Total (merchandise + services) exports & --- & --- & 5.6 & 6.3 & 10.1 & 15.5 & 12.2 \\
\hline Merchandise exports & 6.3 & 4.2 & 4.7 & 4.8 & 7.9 & 10.5 & 9.1 \\
\hline Services share in total exports & -- & -- & 15.9 & 23.3 & 20.8 & 30.0 & 24.6 \\
\hline \multicolumn{8}{|l|}{ (c) India's share in, } \\
\hline world merchandise exports & 2.3 & 0.9 & 0.6 & 0.5 & 0.7 & 0.9 & 0.7 \\
\hline World manufacturing exports & --- & $0.7^{\star}$ & 0.5 & 0.5 & 0.6 & 0.8 & 0.7 \\
\hline Merchandise exports from developing countries & --- & $3.2^{*}$ & 1.9 & 1.5 & 2.1 & 2.1 & 2.0 \\
\hline Manufacturing exports from developing countries & --- & $10.2^{*}$ & 4.3 & 2.6 & 2.5 & 2.5 & 2.3 \\
\hline
\end{tabular}

Notes: Based on current US\$ value

* Average for 1962-69.

--- Data not available

Source: Compiled from IMF, International Financial Statistics database and UN, Comtrade database. 
Table 2: Manufacturing Exports from Developing Countries: Ranking of the Top Ten Exporting Countries in Ascending Order of Export Value, 1962/63, 1979/80, 1999/00 and 2005/06 ${ }^{1}$

\begin{tabular}{|c|c|c|c|c|c|c|c|}
\hline \multicolumn{2}{|l|}{$1962 / 63$} & \multicolumn{2}{|l|}{$1979 / 80$} & \multicolumn{2}{|l|}{$1999 / 00$} & \multirow{2}{*}{$\begin{array}{l}2005 / 06 \\
\text { Country }\end{array}$} & \multirow[b]{2}{*}{ Share (\%) } \\
\hline Country & $\begin{array}{l}\text { Share } \\
(\%)\end{array}$ & Country & $\begin{array}{l}\text { Share } \\
(\%)\end{array}$ & Country & $\begin{array}{l}\text { Share } \\
(\%)\end{array}$ & & \\
\hline Hong Kong & 19.8 & Taiwan & 15.9 & China & 25.5 & China & 38.1 \\
\hline India & 17.8 & Hong Kong & 13.0 & Taiwan & 11.0 & Korea & 10.2 \\
\hline China & 9.5 & Korea & 12.7 & Korea & 10.8 & Taiwan & 8.6 \\
\hline Yugoslavia & 5.8 & China & 7.3 & Mexico & 9.2 & Mexico & 6.1 \\
\hline South Africa & 5.2 & Brazil & 5.6 & Malaysia & 6.6 & Malaysia & 5.1 \\
\hline Mexico & 4.1 & Singapore & 4.9 & Singapore & 5.9 & Singapore & 4.2 \\
\hline Taiwan & 3.6 & Mexico & 4.6 & Thailand & 4.0 & Thailand & 3.6 \\
\hline Pakistan & 2.6 & South Africa & 4.3 & Hong Kong & 3.9 & India & 2.7 \\
\hline Singapore & 2.1 & India & 4.3 & Philippines & 2.9 & Brazil & 2.3 \\
\hline Iran & 2.1 & Yugoslavia & 3.2 & India & 2.6 & Turkey & 2.2 \\
\hline Total & 72.7 & & 75.7 & & 82.4 & & 83.3 \\
\hline
\end{tabular}

Note: ${ }^{1}$ Two-year averages

Source: Compiled from UN Comtrade database. 
Table 3: Commodity Composition of Merchandise Exports ${ }^{4}$ (\%)

\begin{tabular}{|c|c|c|c|c|c|c|c|c|c|c|c|c|c|}
\hline & & \multicolumn{4}{|c|}{ Primary products ${ }^{4}$} & \multicolumn{7}{|c|}{ Manufacturing } & \multirow[b]{2}{*}{ Tota } \\
\hline Country/country group & & Total & $\begin{array}{l}\text { Food and } \\
\text { beverages } \\
\text { (SITC 0+1) }\end{array}$ & $\begin{array}{c}\text { Minerals }{ }^{2} \\
\text { SITC 2+68) }\end{array}$ & $\begin{array}{l}\text { Agri. Raw } \\
\text { material } \\
\text { SITC } 4\end{array}$ & Total & $\begin{array}{c}\text { Chemicals } \\
\text { (SITC 5) }\end{array}$ & $\begin{array}{l}\text { Resource- } \\
\text { based } \\
\text { products } \\
\text { (SITC 6) }\end{array}$ & $\begin{array}{l}\text { Machinery } \\
\text { \& transport } \\
\text { equipment }{ }^{5} \\
\text { (SITC7) }\end{array}$ & $\begin{array}{c}\text { ICT } \\
\text { products }\end{array}$ & $\begin{array}{l}\text { Miscellaneous } \\
\text { manufacturing } \\
\text { SITC8 }\end{array}$ & $\begin{array}{c}\text { Clothing \& } \\
\text { footwear } \\
\text { (SITC } \\
84+85)\end{array}$ & \\
\hline \multirow[t]{3}{*}{ Developing Asia $^{1}$} & $1979 / 80$ & 35.0 & 13.7 & 18.7 & 2.7 & 63.0 & 2.9 & 20.4 & 15.6 & 12.5 & 26.3 & 5.5 & 100 \\
\hline & $1989 / 90$ & 16.6 & 8.2 & 7.5 & 0.9 & 82.1 & 3.4 & 15.4 & 32.1 & 25.3 & 25.2 & 16.0 & 100 \\
\hline & $2005 / 06$ & 6.7 & 2.8 & 3.3 & 0.6 & 91.9 & 6.1 & 12.4 & 53.2 & 44.3 & 20.0 & 8.2 & 100 \\
\hline \multirow[t]{3}{*}{ India } & $1979 / 80$ & 41.6 & 24.8 & 15.9 & 1.0 & 57.7 & 2.6 & 40.0 & 8.1 & 0.0 & 14.6 & 11.4 & 100 \\
\hline & $1989 / 90$ & 27.8 & 14.2 & 12.7 & 0.9 & 71.9 & 4.1 & 42.8 & 4.8 & 1.2 & 20.7 & 17.0 & 100 \\
\hline & $2005 / 06$ & 20.6 & 7.6 & 12.6 & 0.4 & 78.1 & 13.1 & 35.5 & 11.5 & 3.9 & 20.0 & 12.7 & 100 \\
\hline \multirow[t]{3}{*}{ China } & $1979 / 80$ & 39.4 & 23.8 & 15.1 & 0.5 & 60.1 & 7.8 & 29.8 & 3.5 & 1.2 & 20.1 & 2.0 & 100 \\
\hline & $1989 / 90$ & 20.0 & 10.9 & 9.0 & 0.2 & 79.4 & 5.4 & 17.6 & 13.2 & 9.3 & 44.2 & 24.3 & 100 \\
\hline & $2005 / 06$ & 4.4 & 2.2 & 2.1 & 0.0 & 94.9 & 3.6 & 13.9 & 48.3 & 41.5 & 30.3 & 12.5 & 100 \\
\hline \multirow[t]{3}{*}{ Korea } & $1979 / 80$ & 11.0 & 7.9 & 2.9 & 0.1 & 88.3 & 3.3 & 23.6 & 16.3 & 13.8 & 29.6 & 27.1 & 100 \\
\hline & $1989 / 90$ & 6.2 & 4.2 & 2.0 & 0.0 & 92.9 & 3.1 & 18.7 & 35.8 & 26.2 & 36.0 & 24.6 & 100 \\
\hline & $2005 / 06$ & 3.6 & 0.9 & 2.7 & 0.0 & 95.2 & 9.9 & 13.7 & 64.1 & 42.3 & 9.0 & 1.0 & 100 \\
\hline \multirow[t]{3}{*}{ Taiwan } & $1979 / 80$ & 12.5 & 9.8 & 2.7 & 0.0 & 86.9 & 3.0 & 24.4 & 23.6 & 17.0 & 36.2 & 11.4 & 100 \\
\hline & $1989 / 90$ & 8.3 & 5.8 & 2.5 & 0.0 & 90.9 & 3.0 & 17.0 & 38.6 & 27.3 & 0.0 & 5.1 & 100 \\
\hline & $2005 / 06$ & 3.5 & 0.9 & 2.7 & 0.0 & 94.9 & 8.9 & 14.2 & 60.0 & 50.8 & 0.0 & 0.1 & 100 \\
\hline \multirow[t]{3}{*}{ Indonesia } & $1979 / 80$ & 92.3 & 25.8 & 63.9 & 2.6 & 7.4 & 1.6 & 4.6 & 1.2 & 1.0 & 1.2 & 0.1 & 100 \\
\hline & $1989 / 90$ & 47.8 & 17.5 & 27.3 & 3.0 & 51.8 & 2.3 & 34.7 & 1.3 & 0.8 & 18.2 & 14.1 & 100 \\
\hline & $2005 / 06$ & 34.1 & 7.9 & 19.8 & 6.4 & 62.7 & 6.0 & 18.0 & 24.5 & 19.7 & 17.6 & 10.5 & 100 \\
\hline \multirow[t]{3}{*}{ Malaysia } & $1979 / 80$ & 75.0 & 5.3 & 56.6 & 13.1 & 24.3 & 0.8 & 14.4 & 14.5 & 13.2 & 3.3 & 0.5 & 100 \\
\hline & $1989 / 90$ & 38.7 & 5.5 & 26.7 & 6.4 & 60.0 & 2.5 & 8.6 & 39.1 & 36.1 & 11.6 & 7.2 & 100 \\
\hline & $2005 / 06$ & 10.1 & 2.0 & 4.1 & 4.0 & 88.4 & 5.1 & 6.4 & 69.7 & 66.3 & 8.0 & 2.2 & 100 \\
\hline \multirow[t]{3}{*}{ Phillipines } & $1979 / 80$ & 65.5 & 24.6 & 31.0 & 9.9 & 32.9 & 1.2 & 8.4 & 10.6 & 9.7 & 14.3 & 1.6 & 100 \\
\hline & $1989 / 90$ & 37.1 & 18.1 & 15.2 & 3.8 & 61.6 & 2.6 & 9.0 & 23.9 & 22.6 & 29.6 & 19.0 & 100 \\
\hline & $2005 / 06$ & 10.1 & 4.7 & 4.4 & 1.0 & 88.2 & 1.0 & 4.0 & 75.3 & 71.9 & 9.2 & 4.4 & 100 \\
\hline
\end{tabular}




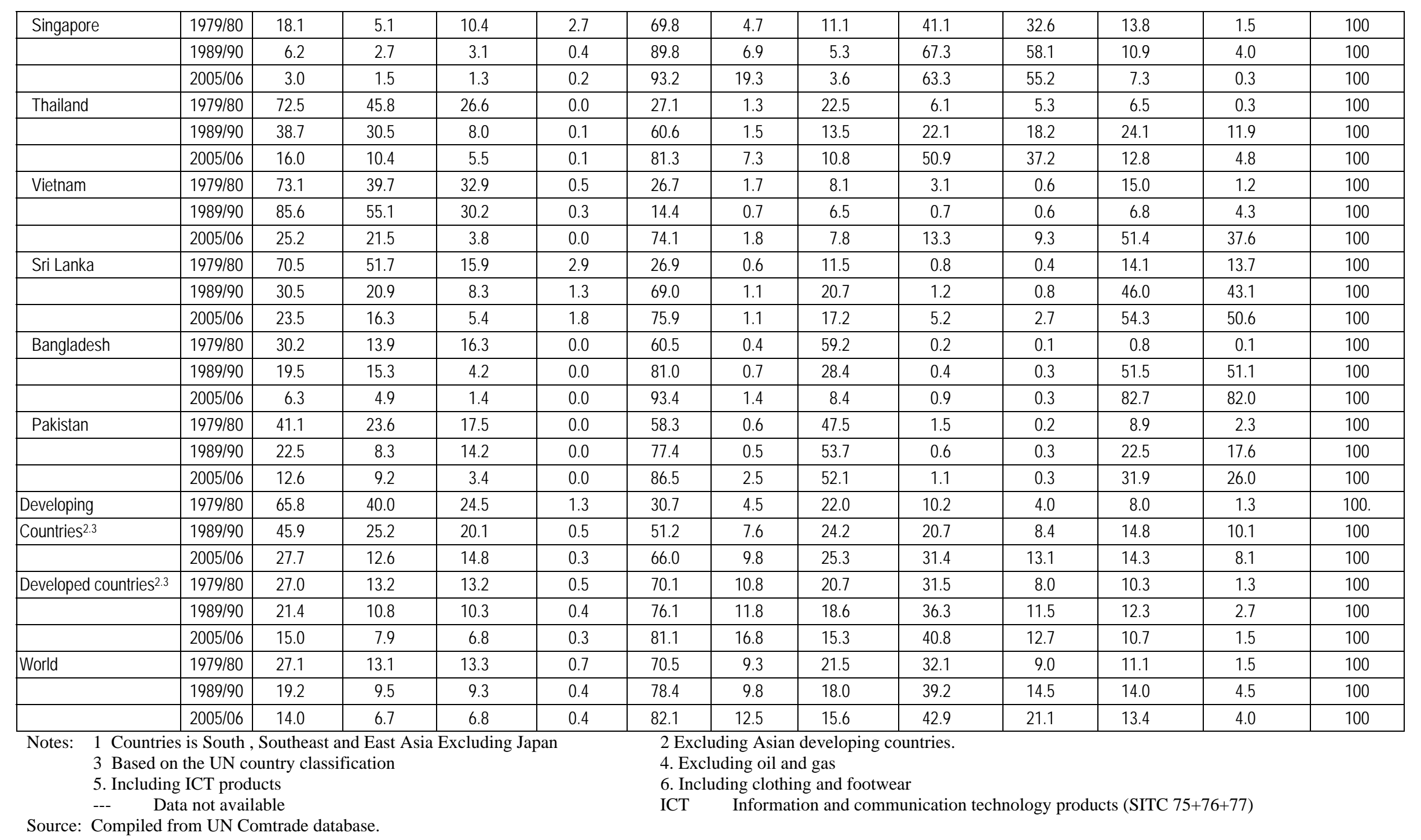


Table 4: Share in World Manufacturing Exports, 1979/80, 1989/90 and 2005/06 (\%)

\begin{tabular}{|c|c|c|c|c|c|c|c|c|}
\hline Country/country group & & Total & $\begin{array}{l}\text { Chemicals } \\
\text { (SITC 5) }\end{array}$ & $\begin{array}{l}\text { Resource- } \\
\text { based } \\
\text { products } \\
\text { (SITC 6) }\end{array}$ & $\begin{array}{r}\text { Machinery \& } \\
\text { transport } \\
\text { equipment }{ }^{4} \\
\text { (SITC7) } \\
\end{array}$ & $\begin{array}{r}\text { ICT products } \\
(\text { SITC 75+ } \\
+76+77)\end{array}$ & $\begin{array}{r}\text { Miscellaneous } \\
\text { manufacturing } \\
\text { SITC8 }\end{array}$ & $\begin{array}{l}\text { Clothing \& } \\
\text { footwear } \\
\text { (SITC } 84+ \\
85 \text { ) } \\
\end{array}$ \\
\hline Developing & $1979 / 80$ & 8.0 & 2.7 & 9.4 & 4.1 & 11.5 & 20.5 & 31.2 \\
\hline \multirow[t]{2}{*}{ Asia } & $1989 / 90$ & 12.8 & 4.2 & 11.3 & 9.5 & 20.2 & 27.6 & 47.8 \\
\hline & $2005 / 06$ & 28.8 & 13.1 & 22.2 & 30.8 & 51.9 & 41.6 & 57.3 \\
\hline \multirow[t]{3}{*}{ India } & $1979 / 80$ & 0.5 & 0.2 & 1.1 & 0.1 & 0.0 & 0.8 & 1.4 \\
\hline & $1989 / 90$ & 0.5 & 0.2 & 1.3 & 0.1 & 0.0 & 0.8 & 2.1 \\
\hline & $2005 / 06$ & 1.0 & 1.1 & 2.3 & 0.3 & 0.2 & 1.5 & 3.2 \\
\hline \multirow[t]{3}{*}{ China } & $1979 / 80$ & 0.9 & 0.8 & 1.4 & 0.1 & 0.1 & 1.8 & 1.3 \\
\hline & $1989 / 90$ & 1.8 & 1.0 & 1.8 & 0.6 & 1.2 & 5.7 & 9.7 \\
\hline & $2005 / 06$ & 13.7 & 3.4 & 10.5 & 13.4 & 23.4 & 26.8 & 37.6 \\
\hline \multirow[t]{3}{*}{ Korea } & $1979 / 80$ & 1.6 & 0.4 & 2.0 & 0.6 & 1.9 & 4.0 & 7.6 \\
\hline & $1989 / 90$ & 2.6 & 0.7 & 2.3 & 2.0 & 3.9 & 5.6 & 11.8 \\
\hline & $2005 / 06$ & 3.6 & 2.4 & 2.7 & 4.6 & 6.2 & 2.1 & 0.8 \\
\hline \multirow[t]{3}{*}{ Taiwan } & $1979 / 80$ & 2.0 & 0.5 & 1.9 & 1.2 & 3.1 & 5.4 & 12.6 \\
\hline & $1989 / 90$ & 2.9 & 0.8 & 2.4 & 2.5 & 4.7 & 0.0 & 2.8 \\
\hline & $2005 / 06$ & 3.1 & 1.9 & 2.5 & 3.8 & 6.6 & 0.0 & 0.1 \\
\hline \multirow[t]{3}{*}{ Indonesia } & $1979 / 80$ & 0.1 & 0.1 & 0.1 & 0.0 & 0.1 & 0.1 & 0.0 \\
\hline & $1989 / 90$ & 0.3 & 0.1 & 0.9 & 0.0 & 0.0 & 0.6 & 1.5 \\
\hline & $2005 / 06$ & 0.7 & 0.4 & 1.0 & 0.5 & 0.8 & 1.1 & 2.3 \\
\hline \multirow[t]{3}{*}{ Malaysia } & $1979 / 80$ & 0.3 & 0.1 & 0.7 & 0.4 & 1.5 & 0.3 & 0.3 \\
\hline & $1989 / 90$ & 0.8 & 0.2 & 0.5 & 1.0 & 2.5 & 0.8 & 1.6 \\
\hline & $2005 / 06$ & 1.8 & 0.7 & 0.7 & 2.8 & 5.4 & 1.0 & 0.9 \\
\hline \multirow[t]{3}{*}{ Philippines } & $1979 / 80$ & 0.2 & 0.1 & 0.2 & 0.2 & 0.6 & 0.7 & 0.6 \\
\hline & $1989 / 90$ & 0.3 & 0.1 & 0.2 & 0.2 & 0.6 & 0.8 & 1.5 \\
\hline & $2005 / 06$ & 0.7 & 0.1 & 0.2 & 1.2 & 2.3 & 0.5 & 0.8 \\
\hline \multirow[t]{3}{*}{ Singapore } & $1979 / 80$ & 0.6 & 0.3 & 0.3 & 0.8 & 2.1 & 0.7 & 0.6 \\
\hline & $1989 / 90$ & 1.2 & 0.8 & 0.3 & 1.8 & 4.3 & 0.8 & 0.9 \\
\hline & $2005 / 06$ & 1.5 & 2.0 & 0.3 & 1.9 & 3.4 & 0.7 & 0.1 \\
\hline \multirow[t]{3}{*}{ Thailand } & $1979 / 80$ & 0.2 & 0.1 & 0.5 & 0.1 & 0.3 & 0.3 & 0.1 \\
\hline & $1989 / 90$ & 0.6 & 0.1 & 0.6 & 0.4 & 1.0 & 1.3 & 2.0 \\
\hline & $2005 / 06$ & 1.3 & 0.8 & 0.9 & 1.5 & 2.3 & 1.2 & 1.6 \\
\hline \multirow[t]{2}{*}{ Vietnam } & $1989 / 90$ & 0.0 & 0.0 & 0.0 & 0.0 & 0.0 & 0.0 & 0.0 \\
\hline & $2005 / 06$ & 0.3 & 0.0 & 0.2 & 0.1 & 0.1 & 1.2 & 2.9 \\
\hline \multirow[t]{3}{*}{ Sri Lanka } & $1979 / 80$ & 0.0 & 0.0 & 0.0 & 0.0 & 0.0 & 0.1 & 0.6 \\
\hline & $1989 / 90$ & 0.1 & 0.0 & 0.1 & 0.0 & 0.0 & 0.2 & 0.6 \\
\hline & $2005 / 06$ & 0.1 & 0.0 & 0.1 & 0.0 & 0.0 & 0.3 & 0.9 \\
\hline \multirow[t]{3}{*}{ Bangladesh } & $1979 / 80$ & 0.0 & 0.0 & 0.1 & 0.0 & 0.0 & 0.0 & 0.0 \\
\hline & $1989 / 90$ & 0.1 & 0.0 & 0.1 & 0.0 & 0.0 & 0.2 & 0.7 \\
\hline & $2005 / 06$ & 0.1 & 0.0 & 0.1 & 0.0 & 0.0 & 0.8 & 2.6 \\
\hline \multirow[t]{3}{*}{ Pakistan } & $1979 / 80$ & 0.1 & 0.0 & 0.3 & 0.0 & 0.0 & 0.1 & 0.2 \\
\hline & $1989 / 90$ & 0.2 & 0.0 & 0.5 & 0.0 & 0.0 & 0.3 & 0.6 \\
\hline & $2005 / 06$ & 0.1 & 0.0 & 0.5 & 0.0 & 0.0 & 0.3 & 0.9 \\
\hline Other & $1979 / 80$ & 3.2 & 3.6 & 7.6 & 2.3 & 3.3 & 5.3 & 6.7 \\
\hline Developing & $1989 / 90$ & 4.3 & 5.0 & 8.8 & 3.4 & 3.8 & 6.8 & 14.5 \\
\hline \multirow[t]{2}{*}{ Countries ${ }^{1 ., 3}$} & $2005 / 06$ & 10.4 & 10.1 & 20.9 & 9.5 & 8.0 & 13.8 & 26.4 \\
\hline & \multicolumn{3}{|c|}{$\begin{array}{l}1 \text { Excluding Asian developing countries. } \\
3 \text { Based on the UN country classification. } \\
5 \text {. Including clothing and footwear } \\
\text { ICT = Information and communication techn }\end{array}$} & $\begin{array}{l}2 \text { Excluding Jap } \\
4 \text { Including ICT } \\
--\quad \text { Date } \\
\text { y products (SITC }\end{array}$ & $\begin{array}{l}\text { ducts. } \\
\text { t available } \\
76+77)\end{array}$ & & & \\
\hline
\end{tabular}

Source: Compiled from UN Comtrade database. 
Table 5: Exports of Machinery \& Transport Equipment, 1989/90 \& 2005/6 (\%)

\begin{tabular}{|c|c|c|c|c|c|c|c|c|}
\hline & \multicolumn{6}{|c|}{ Regional/country composition (\%) } & \multirow{2}{*}{\multicolumn{2}{|c|}{$\begin{array}{c}\text { Share of parts and } \\
\text { components in total } \\
\text { trade }(\%)\end{array}$}} \\
\hline & \multicolumn{2}{|c|}{ Total trade } & \multicolumn{2}{|c|}{$\begin{array}{l}\text { Parts and } \\
\text { components }\end{array}$} & \multicolumn{2}{|c|}{ Final goods } & & \\
\hline & $1989 / 90$ & $2005 / 6$ & $1989 / 90$ & $2005 / 6$ & $1989 / 90$ & $2005 / 6$ & $1989 / 90$ & $2005 / 6$ \\
\hline Developing East Asia & 15.4 & 26.1 & 16.5 & 28.4 & 14.7 & 24.2 & 43.9 & 48.2 \\
\hline Rep. of Korea & 2.4 & 4.3 & 2.9 & 4.1 & 2.1 & 4.4 & 49.0 & 42.8 \\
\hline Taiwan & 3.3 & 3.8 & 3.6 & 5.4 & 3.1 & 2.5 & 45.0 & 63.8 \\
\hline China & 2.3 & 9.3 & 1.4 & 7.3 & 3.0 & 10.9 & 24.5 & 34.8 \\
\hline Hong Kong, SAR & 1.0 & 0.7 & 1.4 & 1.0 & 0.8 & 0.5 & 55.6 & 60.4 \\
\hline AFTA & 6.3 & 8.0 & 7.2 & 10.5 & 5.7 & 6.0 & 46.7 & 58.4 \\
\hline Indonesia & 0.1 & 0.5 & 0.1 & 0.6 & 0.2 & 0.5 & 31.1 & 48.4 \\
\hline Malaysia & 2.1 & 2.8 & 2.4 & 3.8 & 1.9 & 2.0 & 46.8 & 59.5 \\
\hline Philippines & 0.4 & 1.2 & 0.7 & 2.0 & 0.2 & 0.6 & 73.7 & 73.5 \\
\hline Singapore & 2.8 & 2.0 & 3.0 & 2.7 & 2.6 & 1.5 & 44.9 & 58.6 \\
\hline Thailand & 0.9 & 1.3 & 1.0 & 1.4 & 0.9 & 1.3 & 43.0 & 45.7 \\
\hline Viet Nam & 0.0 & 0.1 & 0.0 & 0.1 & 0.0 & 0.1 & 25.8 & 55.9 \\
\hline India & 0.1 & 0.2 & 0.1 & 0.3 & 0.1 & 0.2 & 30.8 & 26.4 \\
\hline Oceania & 0.3 & 0.3 & 0.3 & 0.3 & 0.3 & 0.3 & 39.6 & 43.8 \\
\hline NAFTA & 22.4 & 18.1 & 24.5 & 19.7 & 21.0 & 16.7 & 44.9 & 48.4 \\
\hline EU 15 & 35.3 & 35.4 & 32.5 & 31.1 & 37.3 & 38.9 & 37.9 & 38.9 \\
\hline World & 100 & 100 & 100 & 100 & 100 & 100 & 41.1 & 44.3 \\
\hline US\$ billion & 1379 & 3110 & 567 & 1378 & 812 & 1732 & & \\
\hline
\end{tabular}

Source: Compiled from UN Comtrade database 
Table 6: India's Exports ${ }^{1}$ by 3-digit SITC Categories: Share in total exports, World market Share and RCA Indices ${ }^{2}$

\begin{tabular}{|c|c|c|c|c|c|c|c|c|c|c|}
\hline & & \multicolumn{3}{|c|}{ Export share (\%) } & \multicolumn{3}{|c|}{ Share in world exports (\%) } & \multicolumn{3}{|c|}{$R C A$ index ${ }^{3}$} \\
\hline $0 / 1$ & Food, beverages and tobacco & $1980 / 81$ & $1990 / 91$ & $2004 / 5$ & $1980 / 81$ & $1980 / 82$ & $1980 / 83$ & $1980 / 81$ & $1990 / 91$ & $2004 / 5$ \\
\hline 25 & Eggs & 0.05 & 0.01 & 0.08 & 0.42 & 0.20 & 3.12 & 0.59 & 0.31 & 3.09 \\
\hline 31 & Fish, fresh \& simply preserved & 3.45 & 3.16 & 1.63 & 2.84 & 2.11 & 2.73 & 3.97 & 3.24 & 2.69 \\
\hline 32 & Fish, in airtight containers nes \& fish preptns. & 0.02 & 0.00 & 0.16 & 0.07 & 0.01 & 1.01 & 0.10 & 0.01 & 1.00 \\
\hline 41 & Wheat including spelt and meslin, unmilled & 0.18 & 0.22 & 0.27 & 0.11 & 0.27 & 1.22 & 0.15 & 0.41 & 1.21 \\
\hline 42 & Rice & 3.52 & 1.61 & 1.76 & 6.84 & 7.24 & 17.82 & 9.54 & 11.14 & 17.61 \\
\hline 43 & Barley, unmilled & 0.05 & 0.00 & 0.00 & 0.12 & 0.00 & 0.02 & 0.17 & 0.00 & 0.02 \\
\hline 45 & Other cereals, unmilled & 0.00 & 0.01 & 0.03 & 0.00 & 0.15 & 1.39 & 0.00 & 0.24 & 1.37 \\
\hline 51 & Fruit, fresh, and nuts excl. Oil nuts & 2.75 & 1.74 & 0.93 & 2.52 & 1.79 & 1.93 & 3.51 & 2.76 & 1.91 \\
\hline 54 & Vegetables, roots \& tubers, fresh or dried & 0.47 & 0.48 & 0.54 & 0.52 & 0.51 & 1.31 & 0.73 & 0.78 & 1.30 \\
\hline 71 & Coffee & 2.99 & 0.81 & 0.36 & 2.56 & 1.97 & 2.35 & 3.58 & 3.03 & 2.32 \\
\hline 74 & Tea and mate & 5.83 & 3.07 & 0.46 & 28.76 & 21.86 & 12.59 & 40.13 & 33.65 & 12.44 \\
\hline 75 & Spices & 1.72 & 0.66 & 0.33 & 15.56 & 9.72 & 10.04 & 21.72 & 14.96 & 9.93 \\
\hline 81 & Feed. Stuff for animals excl.unmilled cereals & 2.20 & 2.04 & 1.11 & 2.08 & 2.40 & 3.05 & 2.90 & 3.69 & 3.02 \\
\hline 121 & Tobacco, unmanufactured & 2.50 & 0.67 & 0.27 & 7.02 & 2.58 & 3.46 & 9.79 & 3.97 & 3.42 \\
\hline 122 & Tobacco manufactures & 0.31 & 0.18 & 0.08 & 0.84 & 0.26 & 0.42 & 1.18 & 0.40 & 0.41 \\
\hline $2+68$ & Crude materials, inedible, except fuels & & & & & & & & & \\
\hline 221 & Oil seeds, oil nuts and oil kernels & 0.47 & 0.37 & 0.37 & 0.57 & 0.66 & 1.36 & 0.79 & 1.01 & 1.34 \\
\hline 261 & Silk & 0.01 & 0.00 & 0.01 & 1.33 & 0.14 & 1.83 & 1.86 & 0.21 & 1.81 \\
\hline 263 & Cotton & 1.68 & 1.69 & 0.45 & 2.85 & 4.48 & 4.16 & 3.98 & 6.89 & 4.12 \\
\hline 264 & Jute & 0.09 & 0.02 & 0.00 & 4.43 & 3.23 & 4.19 & 6.18 & 4.97 & 4.15 \\
\hline 265 & Vegetable fibers, except cotton and jute & 0.00 & 0.00 & 0.01 & 0.08 & 0.02 & 1.44 & 0.11 & 0.04 & 1.42 \\
\hline 266 & Synthetic and regenerated artificial fibers & 0.00 & 0.16 & 0.12 & 0.00 & 0.53 & 1.24 & 0.00 & 0.82 & 1.23 \\
\hline 273 & Stone, sand and gravel & 0.41 & 0.68 & 0.55 & 3.34 & 5.07 & 8.16 & 4.65 & 7.81 & 8.06 \\
\hline 275 & Natural abrasives incl. industrial diamonds & 0.00 & 0.03 & 0.06 & 0.03 & 0.67 & 4.23 & 0.04 & 1.03 & 4.18 \\
\hline 276 & Other crude minerals & 0.63 & 0.27 & 0.20 & 1.37 & 0.94 & 1.69 & 1.91 & 1.44 & 1.67 \\
\hline 281 & Iron ore \& concentrates & 4.77 & 3.33 & 4.19 & 5.81 & 8.15 & 15.63 & 8.11 & 12.54 & 15.44 \\
\hline 282 & Iron and steel scrap & 0.01 & 0.01 & 0.01 & 0.05 & 0.05 & 0.02 & 0.06 & 0.08 & 0.02 \\
\hline
\end{tabular}




\begin{tabular}{|c|c|c|c|c|c|c|c|c|c|c|}
\hline 283 & Ores \& concentrates of non ferrous base metals & 0.50 & 0.37 & 0.51 & 0.48 & 0.65 & 1.27 & 0.67 & 0.99 & 1.26 \\
\hline 291 & Crude animal materials, nes & 0.47 & 0.22 & 0.05 & 3.70 & 1.73 & 0.81 & 5.16 & 2.67 & 0.80 \\
\hline 292 & Crude vegetable materials, nes & 2.16 & 0.97 & 0.64 & 3.79 & 1.54 & 2.45 & 5.29 & 2.36 & 2.42 \\
\hline 4 & Animal and vegetable oils, fats and waxes & & & & & & & & & \\
\hline 411 & Animal oils and fats & 0.00 & 0.00 & 0.02 & 0.02 & 0.02 & 0.57 & 0.03 & 0.04 & 0.56 \\
\hline 422 & Other fixed vegetable oils & 0.25 & 0.27 & 0.27 & 0.58 & 1.29 & 1.61 & 0.82 & 1.99 & 1.59 \\
\hline 431 & Anim./veg. Oils \& fats, processed, and waxes & 0.07 & 0.06 & 0.07 & 0.63 & 0.53 & 1.10 & 0.87 & 0.82 & 1.08 \\
\hline 5 & Chemicals and related products & & & & & & & & & \\
\hline 512 & Organic chemicals & 0.22 & 1.54 & 4.66 & 0.07 & 0.43 & 1.68 & 0.10 & 0.66 & 1.66 \\
\hline 513 & Inorganic .chemicals & 0.06 & 0.62 & 0.63 & 0.06 & 0.72 & 1.54 & 0.08 & 1.11 & 1.52 \\
\hline 531 & Synthetic organic dye stuffs & 0.54 & 1.15 & 0.70 & 2.24 & 3.17 & 5.71 & 3.13 & 4.88 & 5.64 \\
\hline 532 & Dyeing \& tanning extracts, synthetic tanning mat. & 0.01 & 0.02 & 0.03 & 0.42 & 0.80 & 2.10 & 0.58 & 1.24 & 2.08 \\
\hline 541 & Medicinal \& pharmaceutical products & 1.42 & 2.68 & 3.14 & 0.99 & 1.32 & 1.00 & 1.38 & 2.03 & 0.99 \\
\hline 551 & Essential oils, perfume and flavour materials & 0.12 & 0.27 & 0.21 & 0.65 & 1.32 & 1.19 & 0.90 & 2.04 & 1.18 \\
\hline 553 & Perfumery, cosmetics, dentifrices, etc. & 0.68 & 0.59 & 0.22 & 2.16 & 1.04 & 0.45 & 3.02 & 1.60 & 0.44 \\
\hline 554 & Soaps, cleansing \& polishing preparations & 0.65 & 0.56 & 0.08 & 2.18 & 1.57 & 0.29 & 3.04 & 2.42 & 0.29 \\
\hline 6 & Manufactured goods classified by materials & & & & & & & & & \\
\hline 611 & Leather & 4.16 & 2.13 & 0.74 & 11.03 & 4.36 & 3.14 & 15.39 & 6.72 & 3.10 \\
\hline 612 & Manufacture of leather & 1.01 & 2.12 & 0.40 & 9.78 & 13.73 & 3.96 & 13.65 & 21.13 & 3.91 \\
\hline 629 & Articles of rubber nes & 0.40 & 0.66 & 0.85 & 0.37 & 0.62 & 1.24 & 0.51 & 0.95 & 1.22 \\
\hline 651 & Textile yarn and thread & 0.73 & 2.58 & 2.53 & 0.55 & 2.22 & 5.55 & 0.77 & 3.41 & 5.48 \\
\hline 652 & Cotton fabrics, woven & 4.51 & 3.42 & 1.05 & 6.37 & 4.13 & 3.08 & 8.89 & 6.36 & 3.04 \\
\hline 653 & Text fabrics woven ex narrow, spec, not cotton & 3.02 & 2.56 & 1.84 & 1.81 & 1.31 & 2.56 & 2.53 & 2.01 & 2.53 \\
\hline 654 & Tulle, lace, embroidory, ribbons, trimmings & 0.14 & 0.11 & 0.12 & 0.94 & 0.75 & 1.53 & 1.31 & 1.16 & 1.51 \\
\hline 656 & Made up articles, wholly or chiefly of text.mat. & 3.37 & 1.89 & 2.43 & 8.04 & 4.39 & 7.52 & 11.22 & 6.76 & 7.44 \\
\hline 657 & Floor coverings, tapestries, etc. & 2.79 & 2.80 & 1.15 & 6.16 & 6.88 & 8.64 & 8.60 & 10.58 & 8.54 \\
\hline 661 & Lime,cement \& fabr.bldg.mat. Ex glass/clay mat & 0.09 & 0.31 & 0.85 & 0.18 & 0.78 & 4.20 & 0.26 & 1.19 & 4.15 \\
\hline 667 & Pearls and precious and semi precious stones & 8.11 & 14.82 & 13.65 & 4.20 & 10.65 & 14.66 & 5.85 & 16.38 & 14.49 \\
\hline 671 & Pig iron, spiegeleisen, sponge iron. Etc & 0.03 & 0.33 & 0.48 & 0.07 & 1.28 & 1.74 & 0.09 & 1.98 & 1.72 \\
\hline 672 & Ingots \& other primary forms of iron or steel & 0.02 & 0.17 & 1.22 & 0.03 & 0.19 & 1.66 & 0.04 & 0.30 & 1.65 \\
\hline 674 & Universals, plates and sheets of iron or steel & 0.02 & 0.27 & 2.33 & 0.01 & 0.15 & 2.03 & 0.02 & 0.23 & 2.00 \\
\hline
\end{tabular}




\begin{tabular}{|c|c|c|c|c|c|c|c|c|c|c|}
\hline 677 & Iron and steel wire, excluding wire rod & 0.08 & 0.14 & 0.17 & 0.41 & 0.92 & 2.05 & 0.58 & 1.42 & 2.03 \\
\hline 678 & Tubes, pipes and fittings of iron or steel & 0.75 & 0.25 & 1.09 & 0.41 & 0.27 & 2.16 & 0.58 & 0.41 & 2.13 \\
\hline 679 & Iron steel castings forgings unworked, nes & 0.06 & 0.21 & 0.54 & 0.61 & 1.73 & 5.50 & 0.86 & 2.66 & 5.43 \\
\hline 682 & Copper & 0.05 & 0.03 & 1.23 & 0.05 & 0.03 & 1.88 & 0.07 & 0.04 & 1.86 \\
\hline 693 & Wire products ex electric \& fencing grills & 0.17 & 0.10 & 0.12 & 0.73 & 0.57 & 1.19 & 1.02 & 0.88 & 1.18 \\
\hline 694 & Nails, screws, nuts, bolts, rivets etc. & 0.24 & 0.12 & 0.24 & 0.86 & 0.39 & 1.15 & 1.20 & 0.61 & 1.14 \\
\hline 695 & Tools for use in the hand or in machines & 0.77 & 0.40 & 0.42 & 1.35 & 0.68 & 1.28 & 1.89 & 1.04 & 1.27 \\
\hline 696 & Cutlery & 0.03 & 0.08 & 0.09 & 0.22 & 0.55 & 1.10 & 0.31 & 0.85 & 1.08 \\
\hline 697 & Household equipment of base metals & 0.43 & 0.24 & 1.06 & 1.31 & 0.83 & 5.58 & 1.82 & 1.28 & 5.52 \\
\hline 698 & Manufactures of metal, nes & 0.66 & 0.79 & 0.69 & 0.67 & 0.70 & 0.79 & 0.94 & 1.08 & 0.78 \\
\hline 7 & Machinery and transport equipment & & & & & & & & & \\
\hline 733 & Road vehicles other than motor vehicles & 0.91 & 0.63 & 0.27 & 1.93 & 1.26 & 0.81 & 2.69 & 1.94 & 0.80 \\
\hline 8 & Miscellaneous manufactured articles & & & & & & & & & \\
\hline 831 & Travel goods, handbags and similar articles & 0.27 & 0.85 & 0.61 & 1.10 & 1.95 & 2.28 & 1.53 & 3.00 & 2.25 \\
\hline 841 & Clothing except fur clothing & 9.11 & 14.55 & 9.75 & 2.45 & 2.48 & 3.12 & 3.42 & 3.82 & 3.08 \\
\hline 851 & Footwear & 0.00 & 1.06 & 0.90 & 0.00 & 0.71 & 1.39 & 0.00 & 1.10 & 1.37 \\
\hline 863 & Developed cinematographic film & 0.21 & 0.04 & 0.02 & 6.51 & 2.41 & 2.56 & 9.08 & 3.71 & 2.53 \\
\hline 895 & Office and stationery supplies, nes & 0.03 & 0.04 & 0.14 & 0.22 & 0.18 & 1.13 & 0.31 & 0.28 & 1.12 \\
\hline \multirow[t]{3}{*}{897} & Jewelry and gold/silver smiths wares & 0.29 & 1.32 & 4.54 & 0.47 & 1.79 & 9.96 & 0.66 & 2.75 & 9.84 \\
\hline & Number of products with $1<\mathrm{RCA}$ & & & & & & & 37 & 47 & 61 \\
\hline & Export share of products with $1<\mathrm{RCA}$ & & & & & & & 78.00 & 80.82 & 72.16 \\
\hline
\end{tabular}

Notes: $\quad$ 1. Excluding oil and gas (SITC 3)

2. All products with measured revealed comparative advantage ( that is $1<\mathrm{RCA}$ ) in any of the three time points are included in the table.

3. The revealed comparative advantage (RCAI) of a given country (country II) in the export of product $j$ is defined as:

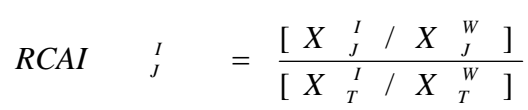

where, $X_{j}^{I} \quad$ is country l's exports of commodity J, $X_{J}^{W}$ is world export of commodity $j, X_{T}^{I}$ is total exports of all goods from country I, and $X_{T}^{W}$ is world exports of all goods. If the value of $R C A I$ exceeds unity for commodity $\mathrm{J}$, the country is said to have 'revealed' comparative advantage in the production of that commodity. In contrast, if $R C A l$ is below one, the country is at a comparative disadvantage in the production of the commodity.

Source: Compiled from UN Comtrade database. 
Table 7: Nominal Tariff in India and Some Asian Countries,

\begin{tabular}{|c|c|c|c|}
\hline Country & Year & $\begin{array}{c}\text { Simple average applied } \\
\text { tariff (\%) }\end{array}$ & $\begin{array}{l}\text { Import-weighted average } \\
\text { applied tariff (\%) }\end{array}$ \\
\hline \multirow[t]{3}{*}{ India } & 1990 & 79.0 & 61.9 \\
\hline & 2000 & 32.7 & 32.2 \\
\hline & 2004 & 28.3 & 25.4 \\
\hline \multirow[t]{3}{*}{ Bangladesh } & 1989 & 106.6 & 88.4 \\
\hline & 2000 & 21.3 & 19.1 \\
\hline & 2004 & 11.7 & 9.0 \\
\hline \multirow[t]{3}{*}{ China } & 1992 & 41.0 & 34.3 \\
\hline & 2000 & 16.2 & 13.0 \\
\hline & 2004 & 9.6 & 5.7 \\
\hline \multirow[t]{3}{*}{ Indonesia } & 1990 & 21.9 & 14.8 \\
\hline & 2000 & 8.4 & 5.9 \\
\hline & 2004 & 8.2 & 6.5 \\
\hline \multirow[t]{3}{*}{ Korea } & 1991 & 19.5 & 16.5 \\
\hline & 2000 & 9.4 & 6.0 \\
\hline & 2004 & 8.6 & 4.1 \\
\hline \multirow[t]{3}{*}{ Malaysia } & 1990 & 16.9 & 10.1 \\
\hline & 2000 & 8.0 & 4.9 \\
\hline & 2003 & 7.4 & 4.9 \\
\hline \multirow[t]{3}{*}{ Pakistan } & 1991 & 66.0 & \\
\hline & 2000 & 23.6 & 43.5 \\
\hline & 2004 & 16.2 & 15.5 \\
\hline \multirow[t]{3}{*}{ Philippines } & 1991 & 26.0 & 15.5 \\
\hline & 2000 & 7.1 & 3.4 \\
\hline & 2004 & 5.5 & 2.0 \\
\hline \multirow[t]{3}{*}{ Sri Lanka } & 1990 & 28.3 & 24.6 \\
\hline & 2000 & 9.3 & 21.0 \\
\hline & 2004 & 9.9 & 6.4 \\
\hline \multirow[t]{3}{*}{ Taiwan } & 1990 & 16.5 & 10.1 \\
\hline & 2000 & 7.3 & 2.9 \\
\hline & 2003 & 6.2 & 2.8 \\
\hline \multirow[t]{3}{*}{ Thailand } & 1991 & 37.8 & 33.9 \\
\hline & 2000 & 16.4 & 9.7 \\
\hline & 2003 & 13.5 & 10.6 \\
\hline \multirow[t]{3}{*}{ Vietnam } & 1992 & 11.0 & 15.8 \\
\hline & 2000 & 15.1 & 13.0 \\
\hline & 2004 & 13.6 & 12.7 \\
\hline
\end{tabular}

Source: Compiled from Nicita and Olarreaga (2006) 
Table 8: Effective Rate of Protection (ERP) in Manufacturing in India and Some Asian Countries

\begin{tabular}{|l|l|l|l|l|}
\hline & Coverage & Year & ERP & Source \\
\hline India & Total manufacturing & $1986-90$ & 107 & Sen (2008) \\
\hline & Consumer goods & & 104 & \\
\hline & Intermediate goods & & 146 & \\
\hline & Capital goods & & 66 & \\
\hline & Total manufacturing & $1996-00$ & 42 & \\
\hline & Consumer goods & & 48 & \\
\hline & Intermediate goods & & 40 & \\
\hline & Capital goods & & 33 & \\
\hline Indonesia & Total manufacturing & 1995 & 25 & Fane and Condon (1996) \\
\hline & & & & \\
\hline Malaysia & Total manufacturing & 2003 & 16 & Athukorala (2005) \\
\hline & & & & \\
\hline Philippines & Total manufacturing & 1999 & 10 & WTO (1999) \\
\hline & & & & \\
\hline Thailand & Total manufacturing & 2004 & 23 & Kohpaiboon and Jongwanich (2007) \\
\hline & & & & \\
\hline Vietnam & Total manufacturing & 2003 & 44 & Athukorala (2006a) \\
\hline
\end{tabular}


Table 9: Indicators of Ease of Trading Across Border: India in the Regional Context, 2008

\begin{tabular}{|l|c|c|c|c|c|c|c|}
\hline & $\begin{array}{c}\text { Documents } \\
\text { for export } \\
\text { (number) }\end{array}$ & $\begin{array}{c}\text { Time for } \\
\text { export } \\
\text { (days) }\end{array}$ & $\begin{array}{c}\text { Cost to } \\
\text { export } \\
\text { (US\$ per } \\
\text { container) }\end{array}$ & $\begin{array}{c}\text { Documents } \\
\text { for import } \\
\text { (number) }\end{array}$ & $\begin{array}{c}\text { Time for } \\
\text { import (days) }\end{array}$ & $\begin{array}{c}\text { Cost to } \\
\text { import } \\
\text { (US\$ per } \\
\text { container) }\end{array}$ & Overall rank $^{1}$ \\
\hline India & 8 & 18 & 820 & 9 & 21 & 910 & 79 \\
\hline Bangladesh & 7 & 28 & 844 & 9 & 32 & 1148 & 112 \\
\hline China & 7 & 21 & 390 & 6 & 24 & 430 & 42 \\
\hline Hong Kong, China & 4 & 6 & 525 & 4 & 5 & 525 & 3 \\
\hline Indonesia & 5 & 21 & 667 & 6 & 27 & 623 & 41 \\
\hline Korea & 4 & 11 & 745 & 6 & 10 & 745 & 13 \\
\hline Malaysia & 7 & 18 & 432 & 7 & 14 & 385 & 21 \\
\hline Pakistan & 9 & 24 & 515 & 8 & 19 & 1336 & 94 \\
\hline Philippines & 8 & 17 & 800 & 8 & 18 & 800 & 57 \\
\hline Singapore & 4 & 5 & 416 & 4 & 3 & 367 & 1 \\
\hline Taiwan, China & 7 & 13 & 747 & 7 & 12 & 747 & 29 \\
\hline Thailand & 7 & 17 & 615 & 9 & 14 & 786 & 50 \\
\hline Vietnam & 6 & 24 & 669 & 8 & 23 & 887 & 63 \\
\hline
\end{tabular}

Notes: 1 The dataset covers 178 countries. This item is further disarregated in Table 10.

Source: World Bank, Doing Business 2008 (http://www.doingbusiness.org/documents/FullReport/2008/DB08_Full_Report.pdf) Source: Doingbusiness database, The World Bank Group (http://www.doingbusiness.org/ExploreEconomies/) 
Table 10: Ease of Doing Business Ranking of Sleeted Asian Countries, 2008

\begin{tabular}{|c|c|c|c|c|c|c|c|c|c|c|c|c|c|c|}
\hline & India & Bangla-desh & China & $\begin{array}{l}\text { Hong } \\
\text { Kong }\end{array}$ & $\begin{array}{l}\text { Indo- } \\
\text { nesia }\end{array}$ & Korea & Malaysia & Pakistan & Philippines & Singapore & Sri Lanka & Taiwan & Thailand & Vietnam \\
\hline Ease of doing business & 120 & 107 & 83 & 4 & 123 & 30 & 24 & 76 & 133 & 1 & 101 & 50 & 15 & 91 \\
\hline Starting a business & 111 & 92 & 135 & 13 & 168 & 110 & 74 & 59 & 144 & 9 & 29 & 103 & 36 & 97 \\
\hline Dealingwith licenses & 134 & 116 & 175 & 60 & 99 & 22 & 105 & 93 & 77 & 5 & 160 & 128 & 12 & 63 \\
\hline Employing workers & 85 & 129 & 86 & 23 & 153 & 131 & 43 & 132 & 122 & 1 & 111 & 148 & 49 & 84 \\
\hline Registering property & 112 & 171 & 29 & 58 & 121 & 68 & 67 & 88 & 86 & 13 & 134 & 24 & 20 & 38 \\
\hline Getting credit & 36 & 48 & 84 & 2 & 68 & 36 & 3 & 68 & 97 & 7 & 97 & 48 & 36 & 48 \\
\hline Protecting investors & 33 & 15 & 83 & 3 & 51 & 64 & 4 & 19 & 141 & 2 & 64 & 64 & 33 & 165 \\
\hline Paying taxes & 165 & 81 & 168 & 3 & 110 & 106 & 56 & 146 & 126 & 2 & 158 & 91 & 89 & 128 \\
\hline Trading across borders & 79 & 112 & 42 & 3 & 41 & 13 & 21 & 94 & 57 & 4 & 60 & 29 & 50 & 63 \\
\hline Enforcing contracts & 177 & 175 & 20 & 1 & 141 & 10 & 63 & 154 & 113 & 4 & 133 & 92 & 26 & 40 \\
\hline Closing business & 137 & 102 & 57 & 15 & 136 & 11 & 54 & 51 & 147 & 2 & 39 & 13 & 44 & 121 \\
\hline
\end{tabular}

* The dataset covers 178 countries. Countries are ranked in ascending order (Best practicing country =1). Data are current as of June 1, 2007.

Source: World Bank, Doing Business 2008 (http://www.doingbusiness.org/documents/FullReport/2008/DB08 Full Report.pdf) 
Figure 1: India's Share in Total World Exports and Exports from Developing Countries, 1962-2006

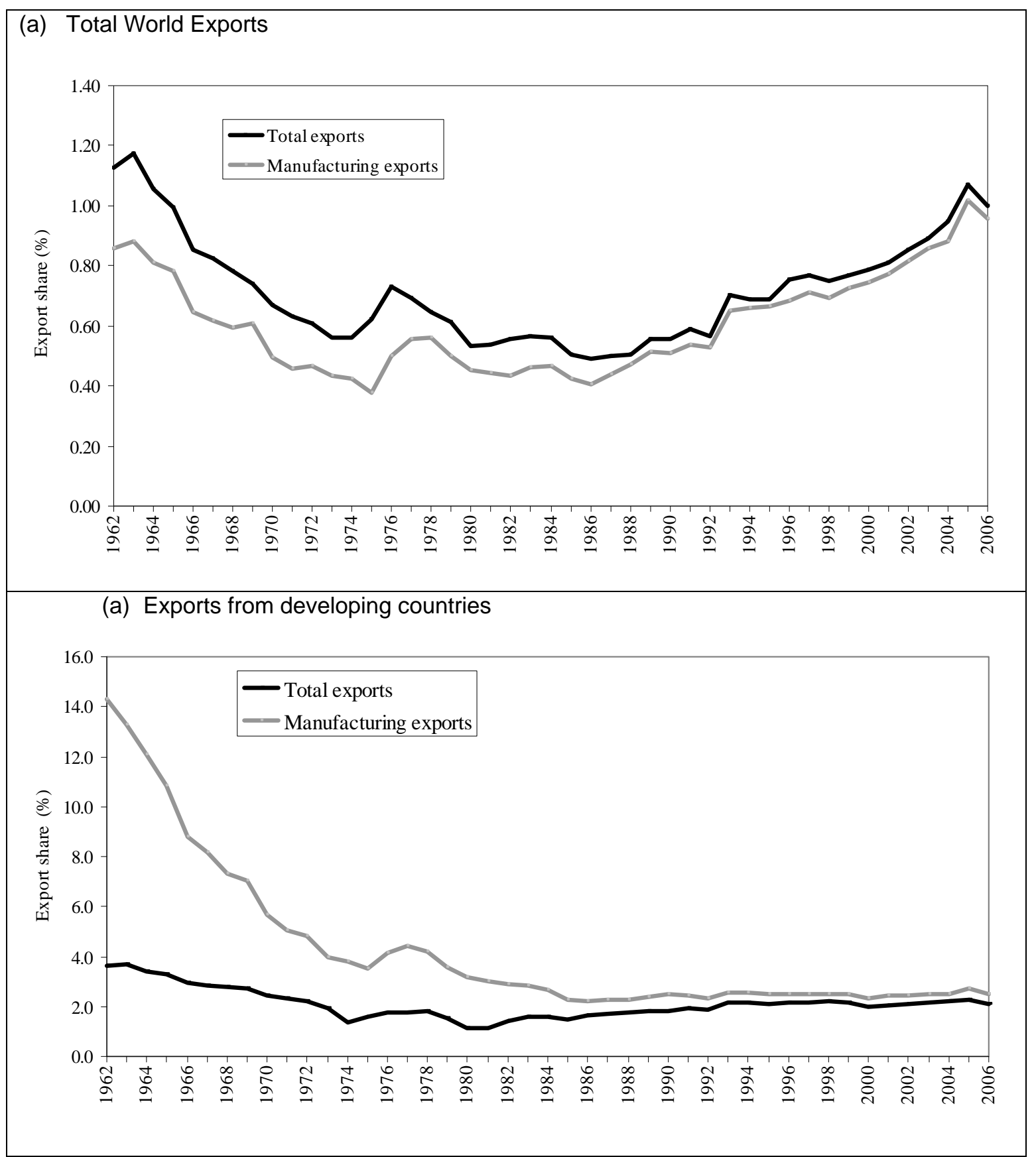

Notes: 1 Total merchandise exports net of oil and gas.

2 Developing countries are identified on the basis of the standard UN definition

Source: Based on data compiled from the UN Comtrade database

Figure 2: Export Orientation of the Indian Economy: Exports as a parentage of GDP), 1970-2005 


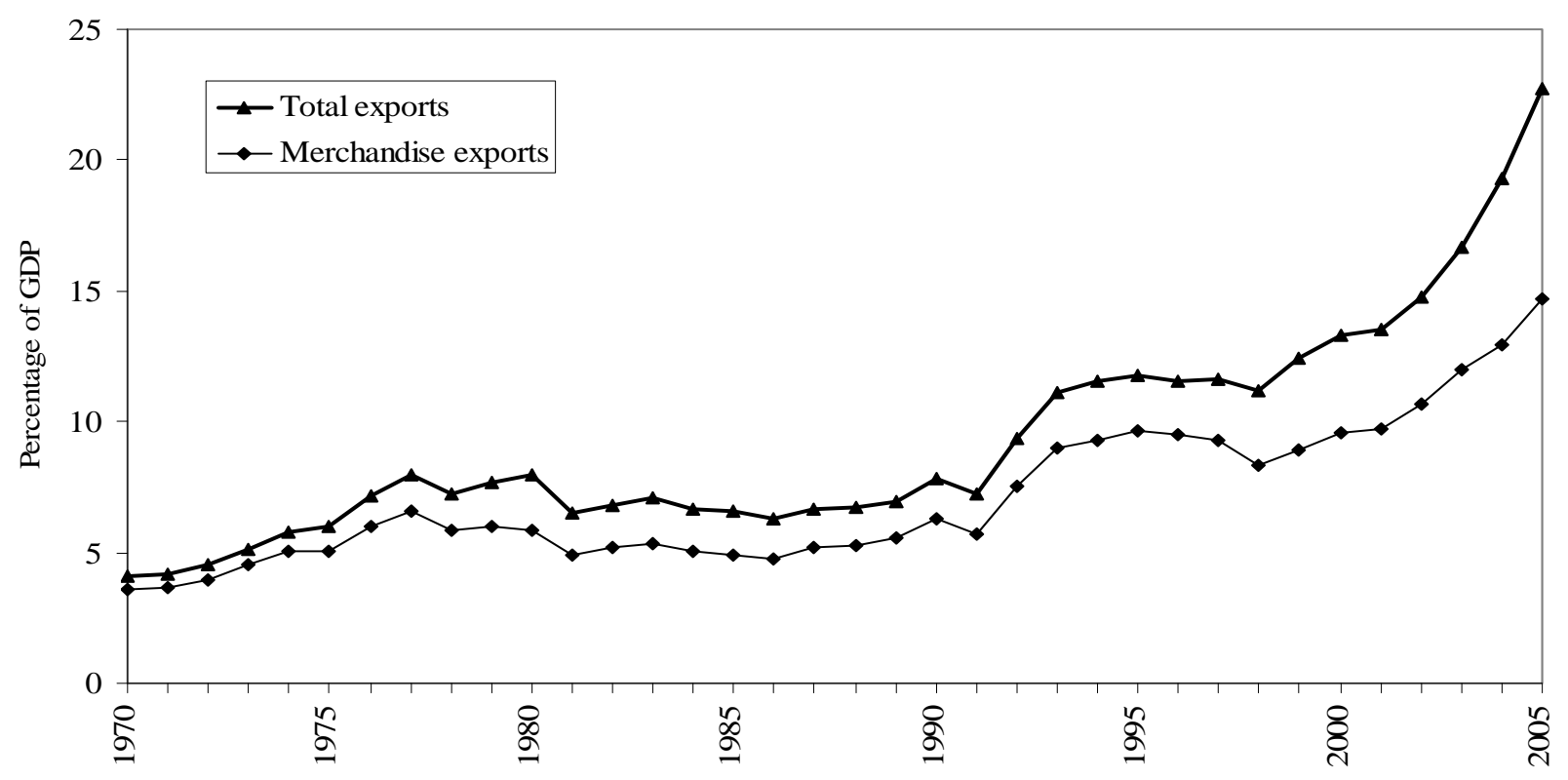

Source: Based on data compiled from IMF, International Financial Statistics database

Figure 3: India and China: Share in world textile and clothing exports, 19802006

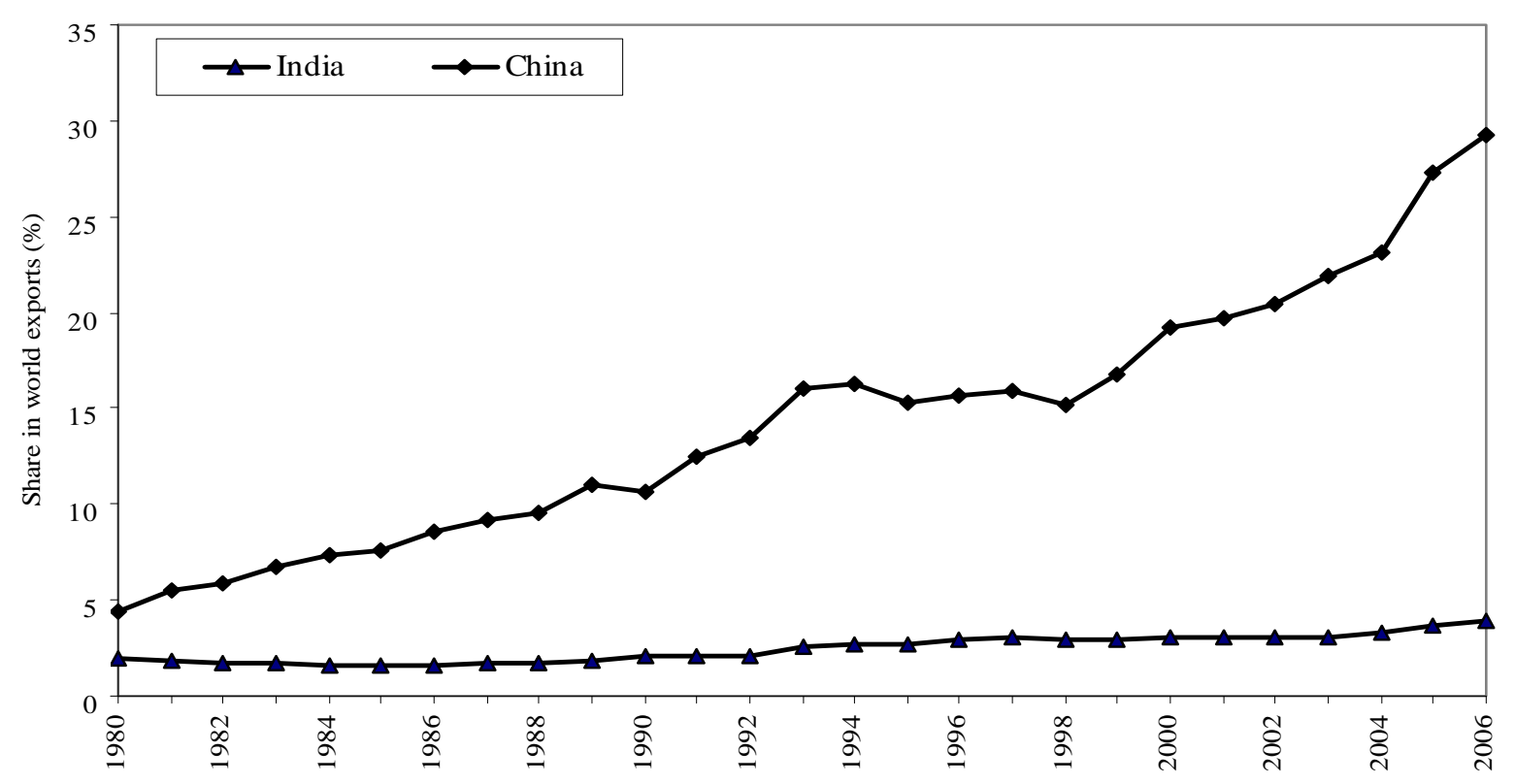

Source: Based on data compiled from UN Comtrade database. 
Figure 4: India: Factor-intensity Classification of Merchandise Exports, 19762005

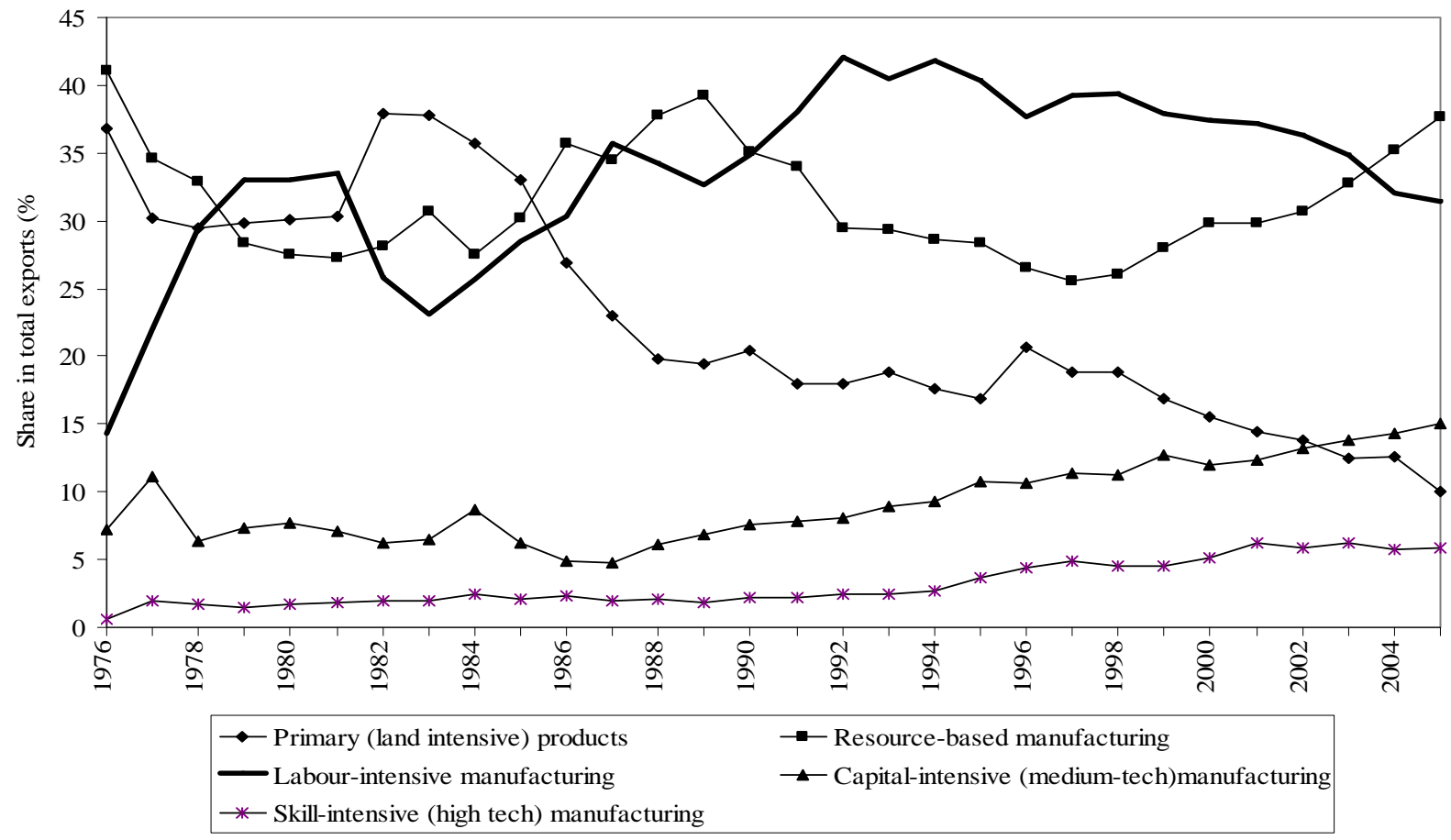

Source: Based on data compiled from UN Comtrade database. 